\title{
8
}

\section{SEVENTEENTH-CENTURY QUAKERS, EMOTIONS, AND EGALITARIANISM}

\section{Sufferings, oppression, intolerance, and slavery}

John Marshall

THE JOHNS HOPKINS UNIVERSITY

The punishments of Quakers for following their religious consciences from the 1650 s to 1680 s included incarceration that led to the deaths of thousands; severe punishments for alleged witchcraft, especially of Quaker women; whippings; being placed in the stocks and pelted with stones; physical assault in the street by soldiers and by crowds; expulsions from many communities; fines; and seizures of household possessions and tools, preventing employments necessary for survival. James Nayler's punishment involved incarceration, 310 lashes, boring of the tongue, and a brand on the forehead, "B" for Blasphemer. As William Penn put it in surveying their 'cruel Sufferings' and 'bitter Persecutions', Quakers were an 'abused and despised people' who 'went forth Weeping and sowed in Tears' and were as 'poor Sheep appointed to the Slaughter, and as a People killed all the Day long'.

We will examine later Quakers' descriptions of themselves as 'weeping and sowed in tears'; it is important to note first that Penn here called Quakers 'despised'. It was common for Quakers to declare that they were 'despised' and 'hated', and therefore persecuted. In 1654, Edward Burrough called his fellow Quakers 'hated and despised'. The opening lines of John Swinton's Testimony for the Lord called Quakers 'despised'. In 1659, Edward Burrough enumerated Quakers' persecutions, whippings, banishments, and imprisonments and queried rhetorically, 'among what sort of people have we not been hated'. Humphrey Smith's 1658 The Fruits of Unrighteousness declared Quakers 'hated and persecuted'. The perception that hatred was directed against Quakers was often aligned in Quaker texts with identification of the further emotions of envy, anger, and jealousy as undergirding hostility to them. In his A Summary Account of the Divers Dispensations of God to Men William Penn tied the persecution of Quakers to 'rage', 'angry mind[s]', 'man's wrath', and 'envy'. Viewing the world as a scene of spiritual battle between God's followers and those of the 
quintessentially 'envious' Satan, Quakers understood their persecution as a consequence of the diabolic 'envy' of the wicked towards the righteous. For Edward Burrough in 1659:

All this Persecution practiced about Religion in the World, that hath been in the World, as Imprisonments, Banishments, Cruel Torture unto death... hath been of the wicked one, through the Malice and Envy of the Devil, against God and his people.

Because wicked rulers knew that 'men that fear God and love righteousness shall take their place', the Devil had filled his servants' hearts with 'ravening envy against the Seed of God'. Humphrey Smith's 1658 Sounding Voyce of the Dread of God's Mighty Power declared persecutors 'filled, and moved with envy'. In his 1662 The Life of Enoch Again Revived, William Bayly declared that those dominated by the flesh were 'fretful, froward and wrath against them, who are in the inward spiritual birth, more righteous than you' as the 'kingdom of pride, subtilty, envy, wrath and persecution' treated those of 'inward birth' as 'prey' to be 'hunted'.

Quakers perceived themselves as hated by their contemporaries. They were right. Across the centuries, 'charitable hatred' had been preached extensively as a Christian duty towards sin in order to prevent its spread to others, and as the 'charitable' loving attempt through coercion to help persuade individuals to reconsider, repent, and thereby be saved. In the parliamentary debate over the fate of Nayler, Edward Goffe declared that out of 'love and charity' it was necessary to execute him. Demand for 'hatred' of sin and 'love' for God was often combined with an invocation of God's 'wrath' and 'righteous anger' to be imitated by humans. God's wrathful punitive interventions in the world, furthermore, were seen as capable of being forestalled by actions to build a 'godly community' of which God would approve. Calls for imitation of God's anger were joined with fear of suffering from that anger if one failed to take godly action against heretics, schismatics, and blasphemers. Thus, the punishment of Nayler was held necessary in order to forestall England's 'national punishment' by turning away 'God's wrath and his Judgments from this land and nation'.

To fear of God's anger for failure to punish Quakers as alleged heretics was often added a fear of the threats posed by Quakers. In this period, heresy was often imaged as a contagious disease murdering souls. Crowds attacked the Quaker Edward Billing in a period when dogs were often rounded up and killed to prevent the spread of the plague, suggesting that they should 'dash out his braines ... [Quakers] are like dogs in time of plague, they are to be killed as they go up and downe the streets, that they do not infect'. Magistrates ordered watches on the highways to keep out Quakers or to expel them to prevent the spread of their 'great contagion'. The Presbyterian Richard Baxter described Quakers as 'like Witches, with Quaking and Vomiting, and infecting others, with breathing on them'. 
Such fear of Quakers as spreading a disease fatal to souls was combined with fear of Quakers as subversive of fragile political order in the inherited vocabulary that classified heretics and schismatics as rebels. That they were feared as such 'rebels' owed much to the challenges Quakers posed for every significant dimension of religious, political, social, and gender hierarchy. Quakers preached the 'inner light' available to all and declared that the world would soon 'be turned upside down'. Quakers identified the gift of prophecy as given to the poor as well as to the rich, and to women as well as to men. Quakers denounced priests zealously as anti-Christian, rejected Anglican houses of worship as idolatrous 'steeple-houses', and refused to pay tithes, thereby refusing support for any variety of a national church in a period when national worship was thought by most to be required to forestall God's anger. Quakers refused oaths, thought to be the only security of political obedience. Quakers did not perform the ceremonies of marriage and rejected the Pauline requirement that women be silent in church, thereby challenging patriarchal, familial, and political order. Quakers rejected all of the quotidian recognitions of social status in dress and demeanour through refusing to doff hats, abandoning politely hierarchical forms of personal address for the egalitarian 'thee' and 'thou', and rejecting clothing associated with hierarchy by instead wearing austere plain cloaks and hats and by going 'naked' for a sign. ${ }^{5}$

In expressing their egalitarian hostility to hierarchy, superfluity, luxury, and pride, Quakers in their early years voiced deeply emotional criticisms of the oppression of the poor by the rich in England and acclaimed the expected and imminent millenarian overturning of their society. Nayler attacked the 'covetous and cruel oppressors' who 'grind the face of the poor and needy'. For Fox, the rich man was the 'greatest thief, and it was the 'poor that suffer' with so many 'ready to starve and beg'. James Parnell sounded a Trumpet of the Lord against lords and gentlemen who had obtained 'much earth' by 'fraud, deceit and oppression' and being thus 'exalted above your fellow-creatures ... grind the faces of the poor, and they are as slaves under you, and must toyle under you'. Parnell declared

Woe unto you that are called Lords, Ladies, Knights... Your fellow creatures must labour like slaves under you... They must hunger and thirst and labour when you are eating, drinking and sleeping, and here like Dives you sit at ease, and poor Lazarus lying starving without.

Lordly domination was a violation of God's wishes, according to Nayler, for 'God hath made all men of one mould and one blood to dwell on the face of the earth'. In his Gospel Truth George Fox declared that

he that respects persons, commits Sin... For to respect a Proud Man, because he hath a Gold Ring on his Finger, and fine Apparel, such respects we deny... to set up a Great Man which hath abundance of 
Earth, joyning Field to Field and Land to Land, and respect such above the Poor, this is an Evil Eye; for God cryes Woe unto such, for God hath made all of one Mould, and one Blood, to dwell upon the Face of the Earth, and he is no Respecter of Persons.

Edward Burrough echoed Nayler and Fox in his Account of some Grounds and Reasons of the Innocent Sufferings of the People of God, Called, Quakers, asking

Hath not God made of one mould and one blood all nations to dwell upon the Face of the Earth? And doth not he that respects Persons commit sin?... must it now be an Offence not to put off the Hat, and give respect to the Person of him that hath a Gold Ring, and fine Apparel? Hath not all the earthly Lordship, and Tyranny and Oppression sprung from this ground, by which Creatures hath been exalted, and set up one above another, trampling under Foot and despising the Poor? ${ }^{6}$

Quakers often attacked the law as corruptly protecting the property of the rich. Benjamin Nicholson, who died in prison in 1660, wrote to 'England's rulers' in his 1653 Blast from the Lord, that instead of 'covering the naked, and feeding the hungry, you set out Laws to punish them, my heart bleeds to think of the hard usage of my poor fellow creatures'. Quaker condemnations of priests included accusing them of being those who 'fare sumptuously, grinding the poor to powder in taxation and oppression, you, that have got a great deal of earth into your hands ... let the poor starve in the streets'. Nayler condemned the priest 'that works not at all ... taking by violence what's other men's labours'. For Quakers, worship included all bodily experiences and actions, not only those performed in an identified house of worship or 'church' under the leadership of a priest supported by tithes and considerable wealth. Quakers' dissent from the world's 'worships' and its 'wayes' were often linked. As Thomas Zachary put it in 1657, in challenging the officers of the Army for having turned from formerly fighting for 'Christian liberty' against tyrannical kings and bishops to becoming tyrants who supported religious coercion: 'Your true interest ... lies in the broken, poor, despised People of God dissenting from the world's worship and wayes'.

Especially in their first years during the English Revolution, Quakers' criticisms of hierarchy were combined with stress on God's righteous 'anger' and 'wrath' against pride and luxury, with stress on egalitarian 'love' of mankind, and 'hatred' of the sins of the 'flesh'-of luxury, vanity, idleness, and dissolution. Fox's preaching spoke of the 'Day of the Lord's Wrath' as coming soon, and of God as 'Jealous' and 'Angry'. Fox declaimed in 1653:

O ye great and rich men of the earth! Weep and howl for the misery that is coming... The fire is kindled, the day of the Lord is appearing, a day of howling... All the loftiness of men must be laid low. 
In 1654, Edward Burrough called, in militaristic if perhaps metaphoric language, for the 'Camp of the Lord' to appear as 'an army' and 'wound the lofty and tread under foot the honourable of the earth'. In his Woeful Cry in 1657, Burrough declared that oppressed saints would receive 'authority and dominion' when Christ came to reign, and then 'The saints shall rule with a rod of iron'.

The millennium did not come; the Lord did not appear; Quaker saints never came to rule England with a rod of iron. Instead, there came the Restoration of the Stuart monarchy and the Anglican Church. The persecution of Quakers was expanded as they were imprisoned, tortured, whipped, stoned, beaten, and fined under Charles II. Quakers died in prison in the 1660 s in greater numbers than in the 1650s. As one of their most important responses, Quakers began to publish an extensive body of accounts of their 'sufferings', and emphasized the theme of 'lamentation', which we glimpsed earlier in Penn's description of Quakers as a people 'weeping and sowed in Tears'. John Swinton's 1663 A Testimony for the Lord closed with 'A Lamentation, a lamentation, a lamentation, in the Life, over the Seed, the Oppressed Seed'. Humphry Smith's 1660 A Sad and Mournful Lamentation for the People of These Nations, issued from 'a filthy hoale' in Winchester Prison, claimed a 'true sense of Gods pitty to the precious souls of all mankind', and his 'heart ... broken within me, and mine eyes as fountaines of tears, and a sad lamentation, night and day hath come upon me; and a true mourning'. Smith especially lamented the 'hard hearted blindnesse' of rulers who persecuted those who worshipped 'from the spirit of God' and asserted that he suffered 'grief' for the rulers who would not be able to hide in the approaching 'day of fierce wrath, and fiery indignation, from the jealous God of Majesty'. The 'great men, and the rich men, and the mighty ones of the earth' would, he declared, soon 'mourn and lament' their service of the 'whore of Babylon'. The Irish Quaker John Perrot attempted to convert the Ottoman sultan and the Pope and was incarcerated and tortured by the Inquisition. Perrot described his tortures in 1440 lines of poetry collected as the 1661 A Sea of the Seed's Sufferings, through Which Runs a River of Rich Rejoycing. As Perrot put it,

Hunger, thirst, Nakedness, and Cold, yea, pangs of pain I eat/To which Oppression doth me hold. Tears are my drink and meat/Sighs in the deeps do gird me, as a swadling-band/The Night's black womb of wrath's my bondage in the Land. ${ }^{9}$

Quakers often discussed their incarceration in terms of an imitation of Christ's sufferings, and emphasized God's supporting 'love'. In his 1658 Sounding Voyce of the Dread of God's Mighty Power, Humphrey Smith identified persecutors as following 'the King' of the 'bottomless pit' in thirsting 'for the blood of the innocent', but declared that 
your long tyranny will never wear out the patience we have received, neither can you inflict more punishment than the Lord hath enabled us to bear... we have given up our bodies and souls a living sacrifice unto God, to do or suffer his will. And him that kills the body we feare not, much lesse those that can but whip or imprison but for a few months... there is none can make them afraid with all their threats, unrighteous Laws, bonds... long unjust imprisonments, or death it self.

Clearly thinking of Christ, Smith declared Quakers' suffering 'crowned with honour'. 'The saints', he held, 'rejoiced' that they were counted worthy 'to suffer for his Names sake, who was made perfect through sufferings'. Smith died in prison in $1663 .^{10}$

Quakers emphasized that they received the 'love of God' in the midst of their tribulations, providing consolation and even 'joy' in their sufferings. For John Swinton, writing from prison, Quakers' 'fear and love of the living God, as he is known a God near at hand' was 'uppermost in their inward parts', exercising a conscience free of $\sin$ 'in the spirits of their minds, they being in union with the spirit of truth, it leads them into all truth, and the love of true things'. Quakers were faithful to 'the fear of the living God, that maketh the heart clean'. For Richard Farnsworth and John Whitehead, in prison in 1664, though Quakers were 'hated of the world' and were suffering 'persecutions and banishments', God's 'love' was 'refreshing' and the 'joys of heaven were manifested' in the midst of their tribulations. Isaac Penington wrote from a prison 'so decayed that it was scarce fit for a dog-house' to Friends:

O ye dear plants of the right hand of eternity, fear not what is to come to pass in this visible creation... but sanctify the Lord of Hosts, and let him be your fear and dread... that ye may be satisfied in the openings and overflowings of the love of His heart towards you.

Penington declared that The Lord 'made my bonds pleasant to me' and

my noisome prison... a place of pleasure and delight, where I was comforted by my God night and day, and filled with prayers for His people, as also with love to and prayers for those who had been the means of outwardly afflicting me and others upon the Lord's account. ${ }^{11}$

Quaker sufferings were thus issued as testimonies to their own faith and expressions of their emotions as purified by God. At the same time, Quaker sufferings were clearly issued as an attempt to appeal to the 'tenderness', 'pity', and 'compassion' of readers and to identify persecutors as 'hard-hearted' and lacking in compassion. In Robert Westfield's 1662 Brief Relation of Some of the Cruel, and Inhumane Usage, and Great Persecution and Imprisonment of above Four Thousand Two Hundred and Thirty of the People of God, in Scorn Called Quakers, the 
imprisonments, deaths, violent arrests, and other 'sufferings' of the Quakers throughout England were publicized 'to the King', Council, and nation, in such a manner 'that if there were any Tenderness in People, it were enough to break their Hearts'. This call for tenderness, for 'softening' the 'hard-hearted' in the reading audience, was part of a campaign by Quakers to evoke 'pity' and 'compassion' for their 'sufferings'. The text, like many other Quaker works, emphasized the sufferings of the aged, women, and children, and of 'poor' men, including 'Widowes, Girles, and some of 80 Years of age'. It explicitly depicted those acting against the Quakers as lacking 'pity', as in the description of 'Women great with child [who] have been haled and abused without pitty'. It evoked in readers' minds the sufferings of children with their parents 'cast into Noisome Dungeons' and 'left Fatherless and Motherless'. And it drew readers into the imaginative space of the Quakers' own experiences in prisons, declaring these worse than those executed by Queen Mary:

Queen Maries Law was nothing like this Lingering Martyrdom, that puts Men and Women in Holes, and will not let them have straw nor Meat; and they are fain to ease themselves in the same Room where they Lodg, and Eat, enough to Poyson them; by which several are sick, and some Dead.

It emphasized that Quakers in prison were so thronged 'that they cannot lie down altogether, many not having a Foot square of room a piece allowed them', until they were carried out sick and dead. Quakers were described as 'Fettered' and 'in Irons'. That this was unjust punishment was repeated multiple times, as it was said that the Quakers were 'Innocent' Inn, denied their trades and capacities to employ others, had their families sundered, and were physically abused, all only for peaceful worship and 'keeping their consciences clear' in 'the fear of the lord':

Oh the Hardheartedness, and Unchristian State, to cause so many Men, Women, and Widdows that are Innocent, and for worshipping of God to be cast into Prisons and Dungeons, and their Trades and Husbandry spoiled, their families Ruined, and laid Waste, and their Children left Crying in the Streets! ${ }^{12}$

The leading Quaker Edward Burrough was in prison in Newgate in 1662, together with several hundred Quakers and Baptists, and declared of Quakers' sufferings that 'the nobility of it gains place in many hearts, which are opened in pity and compassion towards innocent sufferers, and many are affected by our great afflictions'. Even Richard Baxter, for whom Quakers were fanatics, heretics, and infecting witches, declared that they were 'so resolute, and gloried in their constancy and sufferings' that 'many turned Quaker, because the Quakers kept their Meetings openly and went to prison for it cheerfully'. In his 1661 The Quakers Plea, Peter Hardcastle declared that 'there is a property in English 
people to affect sufferers, and to suffer for our Religion, will more encline the hearts of people towards us'. Hardcastle tied this to the argument that it was 'reason and equity' to 'allow all people to turn unto, to follow and practice that Religion which they dare trust their own Souls withal'. ${ }^{13}$

We saw earlier that Penington declared that he prayed not only for Quakers but for those 'who have been the means of outwardly afflicting me'. In the Restoration, it became a major theme of Quaker literature that they loved even their persecutors, in imitation of Christ. In Good Advice to the Church of England, William Penn held that Christ's 'whole business to mankind, from first to last, was Love' and that Christ came 'in much Love' and preached and pressed it both to 'Friends and Foes'. His message was 'Love Enemies; do good to them that hate you, forgive those that trespass against you; what you would that other Men should do unto you, do that unto them'. Christ had 'liv'd in love, so he died in Love' and 'pray'd and died for them who put him to Death'. Christ gave thereby 'an example that we also should follow his steps'. In the 1670 Great Case of Liberty of Conscience, Penn declared that Christ was 'so far from persecuting any, that he would not so much as revile his Persecutors, but prayed for them'. This imitatio Christi was combined directly with the 'Peace principle' of Quakers announced in 1661 by Fox, that 'the spirit of Christ ... will never move us to fight and war against any man with outward weapons'. In his 1662 Quakers Plea, Peter Hardcastle stressed that as Quakers held that it was 'not lawful' to 'fight against, or go to war with Carnal Weapons in any wise', they were axiomatically peaceable. ${ }^{14}$

Quaker literature on their sufferings, forgiveness of enemies, and pacifist declaration of refusal to take up arms for any cause was intended to identify Quakers as not to be feared or hated by any, and thereby to dispose people to support their toleration. Quakers' sufferings were an important part of many Quaker works issued in defence of religious toleration. Very heavy emphasis indeed was placed therein on the central principle of Christianity that 'one should do unto others as one would wish they should do unto you'. As Burrough put it in his 1661 Antichrist's Government Justly Detected, persecution was

unrighteous because it is contrary to the command of God, Do ye to others as ye would be done unto; but this imposing in matters of Worship, is a practice done by others, which others would not be done unto by any, and therefore 'tis unrighteous. 15

The Quaker case for toleration often involved the further identification of Christianity as a religion of 'love' and 'charity', with persecution defined as the antithesis of both. In William Penn's 1679 Address to Protestants, one of his many works against the use of force in religion, Penn declared persecution a violation of Christ's 'own Character of himself, which required Christians to be 'Meek in Heart' and 'not only forgiving but loving their very Enemies'. For Penn, the primary cause of persecution was that its supporters had 'no Religion at Heart', 
with the first business of religion 'to soften the Affection'. As he put it, persecutors were 'devoid of natural Affection, their Religion has no Bowels', as they turned 'Widow and Fatherless' out of house and home. True religion instead made men 'love Enemies, do good to them that hate us, and pray for them that despightfully use us'. For Penn, men 'that are angry for God, Passionate for Christ, that can call Names for Religion, and fling Stones and Persecute for Faith, may tell us they are Christians', but they are not. He held that

so much stronger, in Souls truly Religious, is the Power of Love to Mankind than any self-revenging Passion, that from an humble and serious Reflection upon the Mercies and Goodness of God to them, they do not only suppress any rising of Heart against their persecutors,

but instead 'with much softness and charity, commiserate their Ignorance and Fury ... This is to be Religious, and therefore those that Persecute for Religion are Irreligious'. Penn declared that

where no Anger dwells, no Revenge can grow; and if we must love Enemies, there is no Man left to be hated. This is the doctrine of that Jesus, that laid down his Life for all: and this is the end for which he preached it.

There was a need to be 'such as receive Stripes for Christs sake, and not those that beat our Fellow-Servants'. 16

Thereby answering centuries of Christian arguments for 'hatred' and 'righteous anger' to be directed against heretics and schismatics by arguments from 'love', 'charity', and 'doing unto others as you would have them do unto you', Quakers also turned against persecution itself the invocation of God's 'anger' and 'wrath' and the need to fear it and to forestall God's punitive interventions. The epistle dedicatory to William Caton's 1662 Testimony of a Cloud of Witnesses against 'that horrible Evil of Forcing of Conscience, and Persecution about Matters of Religion' declared that it was such persecution that would 'incur Desolation upon the Land, and hasten the Lord's Judgments upon its Inhabitants' and called therefore for 'free, open, publick and perfect Liberty in the exercise of Conscience'. For Burrough, it was imposed worship 'forced by outward power ... [which] grieves and vexes the God of heaven unto wrath and Indignation'. Want of liberty of conscience was 'the Cause whereby the God of Heaven is angry and provoked' and for which he would 'smite Kingdoms'. It was for Burrough a judgement in the 'fear and spirit of the Lord' that it was 'perfectly reasonable, Just and Equal, that every man in the world be permitted his Liberty in the free exercise of his Conscience'. In his 1661 Antichrist's Government Justly Detected, Burrough declared that 'Wars, Tribulations, [and] Contentions' were the terrestrial consequences of intolerance, and if conscience was imposed upon, 'then shall misery and destruction certainly be unto you, 
according to the Justice of God's Vengeance'. Isaac Penington's 1661 Concerning Persecution argued that persecution 'draweth down the wrath of God upon People, Powers, and Governments, where such Persecution is'. ${ }^{17}$

In the second half of the seventeenth century, slavery was expanding massively in British American and Caribbean colonies. Very many Quakers became slave-owners, including some in the large Quaker community in Barbados and in Pennsylvania from its founding as a Quaker colony in 1681. Penn was a slave-owner. Pennsylvania's Quakers dominated government and developed a harsh slave code. Many Quaker masters punished their slaves severely. Quakers started discussing slavery as early as the 1650s. Some seventeenth-century Quakers, including Fox, emphasized the need for conversion, amelioration, and eventual manumission. A very small number of seventeenth-century Quakers developed anti-slavery arguments. As they considered slavery, Fox and these early Quaker exponents of anti-slavery arguments applied many of the arguments and much of the language of emotions documented above. ${ }^{18}$

In 1657, Fox wrote an epistle 'To Friends beyond Sea, that have Blacks and Indian Slaves', which declared that God was 'no Respecter of Persons ... And he hath made all Nations of one Blood to dwell upon the Face of the Earth'. God had commanded men to 'love all Men'. Stressing that the universal light was a gift to all, Fox declared that God 'doth Enlighten every Man, that cometh into the World, that they might believe in the Son'. For Fox, the Gospel was to be

preached to every creature unto Heaven; which is the power that giveth Liberty and Freedom, and is Glad Tidings to every Captivated Creature under the whole Heavens... and so, ye are to have the Mind of Christ, and to be Merciful.

Fox's emphasis here was thus on preaching, conversion, and mercy towards the 'captivated'. In 1671, Fox went to Barbados and held Meetings at the house of a rich Quaker slave-owner where he himself resided. Challenged by Barbadian authorities that Quakers were fomenting rebellion by holding Meetings attended by slaves, in his To the Ministers, Teachers and Priests ... in Barbados, Fox again emphasized conversion and amelioration, asserting that Quakers teach slaves to 'Fear God, and to love their Masters and Mistresses, and to be Faithful and Diligent in their Masters Service and Business; and that then their Masters and Overseers will Love them, and deal Kindly and Gently with them'. In his 1676 Gospel Family Order, Fox again asserted in a universalist, conversionist, and ameliorationist vein that Christ had died 'for the Tawnes and for the Blacks, as well as for you that are called Whites', and that Christ should be preached

to your Ethyopians that are in your Families, that so they may be free Men indeed, and be tender of them and to them, and walk in Love... being (as the Scripture affirms) all of one Blood and of one Mold, to dwell upon the Face of the Earth. 
Applying to slavery the Golden Rule that Quakers had often applied to condemn religious intolerance, Fox suggested that if Quakers were in the 'same Condition' as 'the Blacks are', they would think it 'very great Bondage and Cruelty'. Therefore, 'do you for and to them, as you would willingly have them or any other to do unto you ... bring them to know the Lord Christ'. Suggesting the desirability of manumission, but placing it into a potentially very distant future in the lives of slaves, Fox held that it would be "very acceptable to the Lord', if Masters of Families 'deal so with their servants, the Negroes and Blacks, whom they have bought with their Money, to let them go free after a considerable Term of Years, if they have served them faithfully'. For Fox, such eventually manumitted slaves—and Fox seems to have thought appropriate thirty years of service before manumission-should not then go 'emptyhanded' ${ }^{19}$

Having also held Meetings open to slaves on Barbados in 1675, William Edmundsen later declared that he had been challenged by the governor and Anglican priests that Quakers' inclusion of slaves would make slaves 'Rebel and cut their throats'. Edmundsen declared that he had then responded that bringing slaves to the knowledge of Christ would 'keep them from rebelling', but that 'if they did rebel, and cut their Throats' it would be 'through' the slave-owners 'own Doings, in keeping them in Ignorance, and under Oppression' and starving them 'for want of Meat and Cloaths convenient'. Edmundsen declared in an epistle 'For friends in Maryland, Virginia and other parts of America' that Negroes must 'feel and partake of the liberty of the Gospel ... Did not God make us all of one mould? And did not Jesus Christ shed his blood for us all?' For Edmundsen, God was 'no Respecter of Persons, but of every Nation, Tongue and People that fears God ... And should not we show forth the mercies, and kindness of God to our fellow Creatures?' Christ's command was 'to do to others, as we would have them to do to us; and which of you all would have the blacks or others to make you their Slaves with out hope or expectation of freedom or liberty?' In a further letter 'to Friends', written in Rhode Island in 1676, Edmundsen argued that it would be

acceptable with God, and answer the witness in all, if you did consider their condition of perpetuall slavery, and make their Conditions your own, and soo fulfil the law of Christ, for perpetual slavery is an Agrivasion, and Oppression on the mind.

He ended this letter by challenging his fellow Quakers by asking them, since 'many of you count it unlawfull to make Slaves of the Indians', 'then why the Negroes?'20

The 'Germantown Protest' of 1688 against 'the traffic of men-body', composed and signed by four Dutch and German Quakers in a small community of Germantown, Pennsylvania, argued emphatically that slavery contravened the Golden Rule: 'Is there any that would be done or handled at this manner? Viz, to be sold or made a slave for all the time of his life?' It declared that 
tho' they are Black; we can not conceive there is more Liberty to have them slaves, as it is to have other white ones. There is a saying, that we shall doe to all men, licke as we will be done our selves; macking no difference of what generation, descent or Colour they are.

Those who 'stole men' and those who purchased them 'were a licke'. Celebrating 'liberty of conscience', the Protestors declared 'here ought to be lickewise liberty of the body'; whereas in Europe 'are many oppressed for Conscience Sacke ... here are those oppressed, which are of a black colour'. Slavery was wrong in sundering families, 'separating wifes from husbands', and because 'some sell the children of these poor Creatures to other men'. Identifying the peace principle as undermined by slavery, and declaring that the right of slaves to 'fight for their freedom' was equal to that of slave-owners, the authors of the Germantown Protest declared that if the slaves should 'joint themselves, fight for their freedom and handel their masters and mastrisses, as these did handel them before' would masters then 'tacke the sword at hand and warr against these poor slaves ... have these negers not as much right to fight for their freedom, as you have to keep them slaves? 21

An Exhortation and Caution to Friends Concerning Buying or Keeping of Negroes of 1693 was the first anti-slavery tract printed in America and the first adopted as policy by a Quaker Monthly Meeting-albeit of the splinter Quaker group of self-described 'Christian Quakers', who were followers of George Keith and at that time in the process of causing schism by emphasizing the requirement of belief in Christ's redemption and doctrinal regulation. The 'Christian Quakers' included a former signatory of the 1688 Germantown protest, Abraham op den Graeff, while Keith was surely among those members who had considered in their Meetings the unprinted 'Germantown Protest' in 1688. The Exhortation declared that Christ's Gospel of 'Peace, Liberty and Redemption from Sin, Bondage, and all Oppression' was to be preached 'unto all, without Exception, and that Negroes, Blacks and Tawnies are a real part of Mankind' and 'capable of Salvation, as well as White Men'. All 'sincere Christians' were to be

conformable unto him in Love, Mercy, Goodness and Compassion, who came not to destroy Men's Lives, but to save them, nor to bring any part of Mankind into outward Bondage, Slavery or Misery, nor yet to detain them, or hold them therein, but to ease and deliver the Oppressed and Distressed, and bring into Liberty both inward and outward.

The Exhortation also declared it necessary

that all faithful Friends should discover themselves to be true Christians by having the Fruits of the Spirit of Christ, which are Love, Mercy, Goodness, and Compassion towards all in Misery, and that suffer Oppression and severe usage, so far as in them is possible to ease and relieve them and set them free of their hard Bondage. 
The Exhortation indicated that 'in some places in Europe Negroes cannot be bought and sold for Money, or detained to be Slaves, because it suits not with the Mercy, Love and Clemency that is essential to Christianity'. To buy men and enslave them and their posterity was both a 'great hindrance' to the 'spreading of the Gospel' and the 'occasion of much War, Violence, Cruelty and Oppression'. And slavery transgressed that

Golden Rule and Law, to do unto others what we would have others do to us... as we and our Children would not be kept in perpetual Bondage and Slavery against our Consent, neither should we keep them in perpetual Bondage and Slavery against their Consent, it being such intolerable Punishment to their Bodies and Minds, that none but notorious Criminal Offendors deserve the same. But these have done us no harme; therefore how inhumane is it in us so grievously to oppress them and their Children from one Generation to another.

The Exhortation questioned 'what greater oppression can there be inflicted upon our fellow creatures than is inflicted on the poor Negroes', 'being brought from their own Country against their Wills', with separation of 'the Husband from the Wife, and the Children from the Parents', and because many masters 'exceedingly afflict them and oppress them, not only by continual hard Labour, but by cruel Whippings and other cruel Punishments'. The Exhortation condemned the 'unparalleled Cruelty of these cruel and hard-hearted pretended Christians'. It declared that for their 'Oppressions and Afflictions' God would visit the 'same by his righteous and just Judgments'. It demanded that 'Mercy' instead be shown 'to these poor, afflicted, tormented miserable Slaves'. The Exhortation recommended 'in true Christian Love' that Friends bought slaves only to set them free, and that they emancipated any already bought 'after some reasonable time of moderate Service' that would 'reasonably answer to the Charge of what they have laid out'. ${ }^{22}$

In 1696, the Pennsylvania Quaker William Southeby composed a markedly similar critique of slavery in To Friends and All Whom It May Concerne, declaring that purchasing slaves 'appears to me to Contradict our Great Law-giver's holy precepts and self-denying doctrine, where he saith, whatsoever ye would that men should do unto you, even so do ye unto them'. Southeby held that 'the very act Slavery bearing upon these poor blackamoor's minds of being kept slave during term of Life, both of them and their posterity' was a

barr to stop them for ever comeing trewly to own Christianity, or at least to believe us to be trew followers of our great Lawgiver Christ Jesus who said, whatsoever ye would that men should doe unto you, doe ye unto them.

Southeby argued that purchasers could not 'be altogether clear of the first violence used in taking of them to be Slaves, because we receive them, which still encourages the first violente Act in taeking of them'. For Southeby, they were 
of the same mold that we are of, and Christ tasted death for them as well as us, and hath given them talents to improve as well as us, and if we have a measure of that Divine Love ruling in us that was so large and incomprehensible in him to all mankind, we must manifest it in some degree.

People should not live 'so high and full as now many by oppression of these poor people doth'. For Southeby, it was necessary to agree with those slaves 'we have already', that they would 'serve you so long till they make reasonable satisfaction for what they cost', and then to free them. If not, 'God will heare their Cry, and also avenge it on their Oppressors'. Southeby declared that

the time is come, and comeing that one nation shall not oppress, nor one people another; nor make Slaves of Each other, neither that the Great and merciful God will have respect to any one Sort of People more than to another, either because they are Black or White or Tawnie. ${ }^{23}$

Two years later, the Pennsylvania Quaker Robert Piles challenged the legitimacy of slavery once again by asserting 'the command' of Christ, 'Do unto all men as ye would have all man doe unto you; and wee would not willingly to be slaves tearm of life; also considering that Christ dieing for all mankind, they being a part, though yet ungathered'. Piles identified slavery as based on 'warr one with another' or on being 'stoln', and questioned 'whether our buying of them do not incurredg rather than discurredg them in that wicked work'. Piles worried both that slaves might 'rise in rebellion' and that Quakers therefore would need to 'keep a malisha [militia]; which is against our principles'. Piles suggested that following some Christianization of slaves, Quarterly Meetings could 'bee proper Judges in setting them free', and in determining any remaining term of service so that the master was not at 'too much loss'. And in the same year of 1698 the Maryland Quaker Richard Hill sent a fifteen-line anti-slavery poem to the English Quaker James Dickinson, declaring slaves 'objects of pity' and asking 'who can but lament the innocent cause of the poor ignorant'. The poem declared that the 'groans' of Africans would ascend to Heaven with even more reason than had those of enslaved Jews in Egypt. It questioned 'What Cruell heart so hard them to deny the Enjoying temporall felicity, whom God possess'd with rights and Liberty'. ${ }^{24}$

These radical anti-slavery arguments had little immediate effect. Quaker slave-owning grew in the eighteenth century in Pennsylvania. The 'Germantown Protest' was sent from the Monthly to the Quarterly and then to the Yearly Meeting, where it was shelved. The 'Christian Quakers' supporting the Exhortation were already schismatic, and Keith was repudiated by the Quakers and repudiated them. Piles' criticisms were voiced as personal testimony against his own purchase of slaves. Southeby's protest helped lead the 1696 Philadelphia Yearly Meeting to issue an 'advice' against further importation of slaves, but this was then largely ignored. But these anti-slavery 
writings show the potential the seventeenth-century language of Quaker emotions and egalitarianism had in opposing slavery by viewing humanity as 'all of one blood and mould', and not only arguing for liberty of conscience and religious toleration against fierce religious persecution, but also condemning slavery and its cruelty, oppression, and sufferings, and affirming instead that all humans possessed 'rights and Liberty'. ${ }^{25}$

\section{Notes}

1 William Penn, The preface being a Summary account of the divers dispensations of God to Men (London, 1694), sig C2r. See also Barry Reay, Quakers and the English Revolution (London: Temple Press, 1985); William Braithwaite, The Beginnings of Quakerism (Cambridge: Cambridge University Press, 1955); William Braithwaite, The Second Period of Quakerism (Cambridge: Cambridge University Press, 1961); Christopher Hill, The World Turned Upside Down (New York: Penguin, 1972); Phyllis Mack, Visionary Women (Berkeley: University of California Press, 1992); Rosemary Moore, The Light within Their Consciences (University Park: Penn State Press, 2000); Larry Gragg, The Quaker Community on Barbados (Columbia: University of Missouri Press, 2009); Amanda Herbert, Female Alliances (New Haven: Yale, 2014); John Marshall, Locke, Toleration and Early Enlightenment Culture (Cambridge: Cambridge University Press, 2006).

2 Edward Burrough, The Memorable Works of a Son of Thunder and Consolation (London, 1672), 1, 256-57; Hill, World, 246; Edward Burrough, A Declaration from the People Called Quakers (London, 1659), 9; Edward Burrough, Antichrist's Government Justly Detected (London, 1659), 6-7; John Swinton, A Testimony for the Lord ([London, 1663]), 1; William Penn, The Preface, Being A Summary Account of the Divers Dispensations of God to Men (London, 1694); William Bayly, The Life of Enoch Again Revived (London, 1662), 6-9; Humphrey Smith, The Sounding Voyce of the Dread of God's Mighty Power (London, 1658), 8; Humphrey Smith, The Fruits of Unrighteousness (London, 1658), 3.

3 Alexandra Walsham, Charitable Hatred (Manchester: Manchester University Press, 2006), passim; Mark Goldie, "The Theory of Religious Intolerance in Restoration England," in Ole Peter Grell, Jonathan Israel and Nicholas Tyacke, eds., From Persecution to Toleration (Oxford: Oxford University Press, 1991), 331-68; John Coffey, Persecution and Toleration in Protestant England 1558-1689 (Harlow: Pearson, 2000), passim; Marshall, Locke, passim.

4 Thomas Burton, The Diary of Thomas Burton, 4 vols (London, 1828), 1:34, 55, 58, 68, 71, 77, 108, 110; Reay, Quakers, 106; Marshall, Locke, 296-97 and throughout.

5 Reay, Quakers, passim; Hill, World, passim; Moore, Light, passim; Marshall, Locke, passim; Braithwaite, Beginnings, passim; Braithwaite, Second Period, passim.

6 James Nayler, A Few Words (London, 1654), 21-22; James Nayler, Wisdom from Beneath (London, 1653); George Fox, A Declaration Against All Professions and Professors (London, 1655), 12, quoted in Reay, Quakers, 40; Hill, World, 244, 248; George Fox, Newes Coming up out of the North (London, 1654), 11; Christopher Hill, Liberty against the Law (Harmondsworth: Penguin 1996), 260; James Parnell, A Trumpet of the Lord (London, 1655), 1, quoted in both Reay, Quakers, 39 and Moore, Light, 63-4; Burrough, Works, 97, 500 partly quoted in Christopher Hill, The Experience of Defeat (London: Faber and Faber 1984), 144-46; George Fox, Gospel-Truth Demonstrated (London, 1706), 27; Hill, Experience, 154 and 154n7.

7 Benjamin Nicholson, A Blast from the Lord (London, 1653), 9-10, quoted in Reay, Quakers, 39 and Moore, Light, 63; Richard Farnsworth, Brief Discovery of the Kingdom of Antichrist (London, 1653), 15-16, quoted in Moore, Light, 63; James Nayler, 
A Public Discovery of the Open Blindness of Babel's Builders (London, 1656), 17, quoted in Hill, Experience, 139; Thomas Zachary, A Word to the Officers of the Army (London, 1657), 3-4.

8 Burrough, Works, 671; Hill, The Experience of Defeat, 148-9; Hill, World, 245-46; George Fox, England's Sad Estate (London, 1661), 1-11; George Fox, Gospel Truth Demonstrated (London, 1654); Hill, World, 234.

9 John Swinton, A Testimony for the Lord (London, 1663), 6-7; Humphry Smith, A Sad and Mournful Lamentation for the People of These Nations (London, 1660), 1-6; John Perrot, A Sea of the Seed's Sufferings (London, 1661); Nigel Smith, "Exporting Enthusiasm: John Perrot and the Quaker Epic," in Thomas Healy and Jonathan Sawday, eds, Literature and the English Civil War (Cambridge: Cambridge University Press, 1990), 248-64.

10 Humphry Smith, The Sounding Voyce of the Dread of God's Mighty Power (London, 1658), 6-8.

11 Swinton, Testimony, 2; Richard Farnsworth, Thomas Green and John Whitehead, A Tender Visitation of Heavenly Love (London, 1664), 1-4; Isaac Penington, Works (London, 1681), 1:108; Braithwaite, Second Period, 10.

12 [Robert Westfeild], For the King and His Councill at Whitehall (London, 1662), 1-2.

13 Braithwaite, Second Period, 26, 41; Peter Hardcastle, The Quakers Plea (London, 1661), 4-5, 13-4.

14 William Penn, Good Advice to the Church of England (London, 1687), 2-3; William Penn, Great Case of Liberty of Conscience ([London], 1670), cii; George Fox, A Declaration from the Harmless and Innocent People of God Called Quakers (London, 1661), 2-3 in Hill, Experience, 161; Peter Hardcastle, Quakers Plea (London, 1662), 4-5.

15 Burrough, Antichrist's Government, 9.

16 William Penn, Address to Protestants (London, 1679), 100-102, 199-200, 203, 230-32, 242.

17 William Caton, The Testimony of a Cloud of Witnesses (London, 1662), title-page; Epistle Dedicatory, sig. A2v; Epistle to the Reader, sig. A1r; Burrough, Works, 848-9; Isaac Penington, Concerning Persecution (London, 1661), 23.

18 Thomas Drake, Quakers and Slavery in America (New Haven: Yale University Press, 1950), 1-33; David Brion Davis, The Problem of Slavery in Western Culture (Ithaca: Cornell University Press, 1966), 291-332; Jean Soderlund, Quakers and Slavery (Princeton: Princeton University Press, 1985), 15-22, 32-39; Gary Nash and Jean Soderlund, Freedom by Degrees (New York: Oxford University Press 1991), 3-16; Kristen Block, "Cultivating Inner and Outer Plantations," Early American Studies (2010): 515-48.

19 George Fox, A Collection of Many Select and Christian Epistles (London, 1698), 117; George Fox, Gospel Family Order (London, 1676), 13-19; George Fox, To the Ministers, Teachers and Priests ... in Barbados (London, 1672), 69. For important analyses of these texts and their contexts, see Brycchan Carey, From Peace to Freedom (New Haven: Yale University Press, 2012), chap. 1; Gragg, Quaker Community; Block, "Cultivating"; Davis, Problem, 304; William Frost, "George Fox's Ambiguous AntiSlavery Legacy," in Michael Mullett, ed., New Light on George Fox (York: William Sessions, 1994), 69-88.

20 Frost, Quaker, 61-2, 66-8. See Carey, Peace to Freedom, 58-66; Gragg, Quaker, chap. 7; Davis, Problem, 307. On Curwen see Carey, Peace to Freedom, 66-69.

21 Carey, Peace to Freedom, 74-76 provides an excellent transcription of the text, adopted here; see also chap. 1-2 for its discussion; Katharine Gerbner, "We Are against the Traffic of Men-Body," Pennsylvania History: A Journal of Mid-Atlantic Studies (2007): 149-72; J. William Frost, ed., The Quaker Origins of Antislavery (Norwood, PA: Norwood Editions 1980); Drake, Quakers, 11-13; Davis, Problem, 308-9.

22 An Exhortation and Caution to Friends Concerning Buying or Keeping of negroes (New York, 1693); J. William Frost, The Keithian Controversy in Early Pennsylvania (Norwood, PA: Norwood Editions, 1980); Davis, Problem, 309-11; Katharine 
Gerbner, "Antislavery in Print: The Germantown Protest, the Exhortation, and the Seventeenth-Century Quaker Debate on Slavery," Early American Studies (2011): 552-75; Carey, Peace to Freedom, 86-95; Thomas Slaughter, The Beautiful Soul of John Woolman: Apostle of Abolition (New York: Hill and Wang, 2008), 108-10.

23 Nicholas Wood and Jean Soderlund, “To Friends and All Whom It May Concerne': William Southeby's Rediscovered 1696 Antislavery Protest," Pennsylvania Magazine of History and Biography 141, no.2 (2017): 177-98, especially 192-96.

24 Frost, Quaker Origins, 71-72; Gragg, Quaker Community, 128; Davis, Problem, 311-12; Slaughter, Woolman, 108-110; Frost, "Ambiguous Legacy," 77, 81-83.

25 Davis, Problem, 291-332; Carey, Peace to Freedom; Gerbner, "Antislavery"; Gerbner "Traffic"; Block, "Cultivating"; Nash and Soderlund, Freedom; Wood and Soderlund, "To Friends"; Slaughter, Woolman.

\section{Bibliography}

Bayly, William. The Life of Enoch Again Revived. London, 1662.

Block, Kristen. "Cultivating Inner and Outer Plantations." Early American Studies 8, no.3 (2010): 515-48.

Braithwaite, William. The Beginnings of Quakerism. Cambridge: Cambridge University Press, 1955.

Braithwaite, William. The Second Period of Quakerism. Cambridge: Cambridge University Press, 1961.

Burrough, Edward. Antichrist's Government Justly Detected. London, 1659.

Burrough, Edward. A Declaration from the People Called Quakers. London, 1659.

Burrough, Edward. The Memorable Works of a Son of Thunder and Consolation. London, 1672.

Burton, Thomas. The Diary of Thomas Burton. London, 1828.

Carey, Brycchan. From Peace to Freedom. New Haven: Yale University Press, 2012.

Caton, William. The Testimony of a Cloud of Witnesses. London, 1662.

Coffey, John. Persecution and Toleration in Protestant England 1558-1689. Harlow: Pearson, 2000.

Davis, David Brion. The Problem of Slavery in Western Culture. Ithaca: Cornell University Press, 1966.

Drake, Thomas. Quakers and Slavery in America. New Haven: Yale University Press, 1950.

Farnsworth, Richard. Brief Discovery of the Kingdom of Antichrist. London, 1653.

Farnsworth, Richard, Thomas Green, and John Whitehead, A Tender Visitation of Heavenly Love. London, 1664.

Fox, George. Gospel Truth Demonstrated. London, 1654.

Fox, George. Newes Coming up out of the North. London, 1654.

Fox, George. A Declaration against All Professions and Professors. London, 1655.

Fox, George. A Declaration from the Harmless and Innocent People of God Called Quakers. London, 1661.

Fox, George. England's Sad Estate. London, 1661.

Fox, George. Gospel Family Order. London, 1676.

Fox, George. A Collection of Many Select and Christian Epistles. London, 1698.

Fox, George. Gospel-Truth Demonstrated. London, 1706.

Fox, George. To the Ministers, Teachers and Priests ... in Barbados. London, 1672.

Frost, J. William. The Keithian Controversy in Early Pennsylvania. Norwood, PA: Norwood Editions, 1980. 
Frost, J. William. "George Fox's Ambiguous Anti-Slavery Legacy.” In New Light on George Fox, edited by Michael Mullett, 69-88. York: William Sessions, 1994.

Frost, J. William, ed. The Quaker Origins of Antislavery. Norwood, PA: Norwood Editions, 1980.

Gerbner, Katharine. "We Are Against the Traffic of Men-Body." Pennsylvania History: A Journal of Mid-Atlantic Studies 74, no.2 (2007): 149-72.

Gerbner, Katharine. "Antislavery in Print: The Germantown Protest, the Exhortation, and the Seventeenth-Century Quaker Debate on Slavery." Early American Studies 9, no.3 (2011): 552-75.

Goldie, Mark. "The Theory of Religious Intolerance in Restoration England.” In From Persecution to Toleration, edited by Ole Peter Grell, Jonathan Israel and Nicholas Tyacke, 33168. Oxford: Oxford University Press, 1991.

Gragg, Larry. The Quaker Community on Barbados. Columbia: University of Missouri Press, 2009.

Hardcastle, Peter. The Quakers Plea. London, 1661.

Herbert, Amanda. Female Alliances. New Haven: Yale, 2014.

Hill, Christopher. The World Turned Upside Down. New York: Penguin, 1972.

Hill, Christopher. The Experience of Defeat. London: Faber and Faber, 1984.

Hill, Christopher. Liberty against the Law. Harmondsworth: Penguin, 1996.

Keith, George. An Exhortation and Caution to Friends Concerning Buying or Keeping of negroes. New York, 1693.

Mack, Phyllis. Visionary Women. Berkeley: University of California Press, 1992.

Marshall, John. Locke, Toleration and Early Enlightenment Culture: Religious Intolerance and Arguments for Religious Tolerance in Early Modern and 'Early Enlightenment' Europe. Cambridge: Cambridge University Press, 2006.

Moore, Rosemary. The Light within Their Consciences. University Park: Penn State Press, 2000.

Nash, Gary and Jean Soderlund. Freedom by Degrees. New York: Oxford University Press, 1991.

Nayler, James. Wisdom from Beneath. London, 1653.

Nayler, James. A Few Words. London, 1654.

Nayler, James. A Public Discovery of the Open Blindness of Babel's Builders. London, 1656.

Nicholson, Benjamin. A Blast from the Lord. London, 1653.

Parnell, James. A Trumpet of the Lord. London, 1655.

Penington, Isaac. Concerning Persecution. London, 1661.

Penington, Isaac. Works. London, 1681.

Penn, William. Great Case of Liberty of Conscience. London, 1670.

Penn, William. Address to Protestants. London, 1679.

Penn, William. Good Advice to the Church of England. London, 1687.

Penn, William. The preface being a Summary account of the divers dispensations of God to Men. London, 1694.

Perrot, John. A Sea of the Seed's Sufferings. London, 1661.

Reay, Barry. Quakers and the English Revolution. London: Temple Press, 1985.

Slaughter, Thomas. The Beautiful Soul of John Woolman: Apostle of Abolition. New York: Hill and Wang, 2008.

Smith, Humphrey. The Fruits of Unrighteousness. London, 1658.

Smith, Humphrey. The Sounding Voyce of the Dread of God's Mighty Power. London, 1658.

Smith, Humphrey. A Sad and Mournful Lamentation for the People of These Nations. London, 1660.

Smith, Nigel. "Exporting Enthusiasm: John Perrot and the Quaker Epic." In Literature and the English Civil War, edited by Thomas Healy and Jonathan Sawday, 248-264. Cambridge: Cambridge University Press, 1990. 
Soderlund, Jean. Quakers and Slavery. Princeton: Princeton University Press, 1985.

Swinton, John. A Testimony for the Lord. London, 1663.

Walsham, Alexandra. Charitable Hatred. Manchester: Manchester University Press, 2006.

Westfeild, Robert. For the King and His Councill at Whitehall. London, 1662.

Wood, Nicholas, and Jean Soderlund. "'To Friends and All Whom It May Concerne':

William Southeby's Rediscovered 1696 Antislavery Protest." Pennsylvania Magazine of History and Biography 141 (2017): 177-98.

Zachary, Thomas. A Word to the Officers of the Army. London, 1657. 